\title{
Silhoutte of Muslim Minority Girls Pursuing College Education: A Case Study of Al-Ameen College, Belgaum
}

\author{
${ }^{1}$ Dr. Z. A. Pathan, ${ }^{2}$ Mr. Md M. A. Mujawar \\ ${ }^{l}$ H.O.D. Department of Sociology, Al-Ameen College, Belgaum, Karnataka. \\ ${ }^{2}$ Research Scholar, CMJ University, Meghalaya, Shillong.
}

\section{Introduction}

There has been a gap between the education of boys and girls in India in the case of Muslims the gap has been a yawning chasm. The education of girls has always demanded higher investment in terms of more facilities, more women teachers, separate schools, transport and scholarships to provide the much-needed incentives. While there are numerous instances of minority-run institutions among Christians, Sikhs and Parsis that have made special efforts to provide free education to their girls, among Muslim faith-based organisations this consciousness has been late in coming.

Those involved in the education of the Muslim girl child have not been able to reach any consensus on the sort of education to be given to the Muslim girl child and ambivalences persist about the merits of Deeni Taalim (religious education) vs Duniyawi Taalim(worldly education). Meanwhile, there is a growing hunger for education among Muslim girls and women that can no longer be ignored.

\section{Definition of Minority:}

Feagin defines that "a minority group has five characteristics: (1) suffering discrimination and subordination, (2) physical and/or cultural traits that set them apart, and which are disapproved by the dominant group, (3) a shared sense of collective identity and common burdens, (4) socially shared rules about who belongs and who does not determine minority status, and (5) tendency to marry within the group".

\section{OBJECTIVE OF THE STUDY}

The main objective of the present study is to analyse the socio-economic background, aims and aspirations of the Muslim Minority Girl Students pursuing education at Al-Ameen Pre-University College, Belgaum.

\section{SELECTION OF RESPONDENTS:}

After resolving the nature and respondents for this research work, information is compiled through well-processed questionnaires by contacting students pursuing education at Al-Ameen Pre-University College in arts department.

The departments approached for this purpose are:

$\Rightarrow$ Educational Institutions.

$\Rightarrow$ Government offices

$\Rightarrow$ Educational Societies in Belgaum District.

$\Rightarrow$ Personal contacts.

In the current study 60 students from Al-Ameen Pre-University College of Belgaum District are preferred for the collection of primary data. The students pursuing education in Al-Ameen P.U. College are selected through random sampling technique.

\section{Methodology}

The study is based on both Primary and Secondary data. A case study method was employed to study 60 Girls studying in Al-Ameen Pre-University College, Belgaum, in the month of September-October 2012. A pre-structured questionnaire was prepared and administered to the respondents to obtain the data. Secondary data was obtained from published literature of the government and academicians.

\section{LOCALE OF THE STUDY}

In 1992-93 Al-Ameen Progressive Educational Society opened a new Institute named Al-Ameen PreUniversity College at Belgaum where facilities are available for Pre-University course in Arts and Commerce discipline. It is proposed to start science courses during 2013-14. As Al-Ameen P.U.College is a Minority institute it has more representation of girl students coming from traditional Muslim family. 
Belgaum, The study area is located in the northwestern part of the Karnataka State and falls within the northern maidan region. The Belgaum district (named after its Head Quarters - Belgaum) extends between $\mathbf{1 5 . 2 3}^{\mathbf{0}}$ and $\mathbf{1 6 . 5 8}^{\mathbf{0}}$ north latitude and $\mathbf{7 5 . 5}^{\mathbf{0}}$ and $\mathbf{7 5 . 8}^{\mathbf{0}}$ east longitude. Dharwad and Uttar Kannada districts bound the district in the north by Sangli and Kolhapur districts and on the west by parts of Kolhapur and Ratnagiri of Maharashtra State and Goa on the east by Bijapur district in the South. It measures about 168 kilometers north to south and $\mathbf{8 0}$ to 138 kilometers east to west

\section{STATEMENT OF THE PROBLEM}

Muslims constitute India's largest minority as well as the second largest Muslim population in the world after Indonesia. Educationally, Muslims constitute one of the most backward communities in the country causing concern. Muslim girls and women lag behind their male counterparts and women of all other communities.

Thus there is an urgent need to analyse Silhoutte of Muslim Minority girls pursuing college education this will not only provide awareness regarding their socio-economic conditions but also help in making government policies and schemes for the development and upliftment of Muslim women.

\section{Literature Review}

Anita Nuna (2003), 'Education of Muslim Girls: A Study of the Area Intensive Programme', studied the impact of the Area Intensive Programme on enrolment and retention of children, particularly Muslim girls in elementary schools and to understand the impact of multi-stream residential higher secondary schools on education of Muslim girls.

In order to seek answers to the objectives and research questions of the study, both the quantitative and qualitative data/ information was applied. The information was based on personal visits to the sampled states/ districts / blocks/institutions through observations, meetings and discussions with all the concerned officials and beneficiaries of the scheme.

Zoya Hasan, \& Ritu Menon (2005) 'Educating Muslim Girls: A Comparison of Five Cities' the book highlights the dismal state of Muslim female education as well as the efforts being made by several Muslim social activists in different parts of India to address the issue.

The authors conclude by stressing the need of Muslim community leaders as well as the state to take the issue of educating Muslim girls with the seriousness that it deserves, they rightly argue, for the state to take a pro-active role in this regard in order to promote social justice and the empowerment of Muslim women and to remove the barriers that systematically reinforce their marginalization.

Z A Pathan (2006) in his thesis entitled "Muslim Elite: A Sociological analysis" have analysed the causes for the emergence and development of muslim elite and the research also exhibits that education plays a great role in the emergence of Muslim elite. As the research was carried in belgaum district and various educational institutions were extensively studied. Importance of Muslim education was highlighted and the study shows that there is less representation of Muslim women in Elite class.

Usha Nayar (2007), 'An Analytical Study of Education of Muslim Women and Girls in India' The present study was commissioned by the Ministry of Women and Child Development, Department of Women and Child Development (DWCD), specifically, the Study has analysed the present literacy and educational status of Muslim Girls and Women in India, the social, cultural and educational factors and forces hindering their educational participation against the backdrop of existing Policies, Programmes and Schemes to promote education of Girls and Women in general and those belonging to educationally backward minorities and other socially and economically disadvantaged sections of our society was studied.

Table No. 1

Age composition of the Respondents

\begin{tabular}{|c|c|c|c|c|c|}
\hline Sl. No & Age & P.U.C I & P.U.C II & $\begin{array}{c}\text { No. of } \\
\text { Respondents }\end{array}$ & Percent \\
\hline 1. & 15 & 01 & 00 & 01 & 01.67 \\
\hline 2. & 16 & 23 & 00 & 23 & 38.33 \\
\hline 3. & 17 & 01 & 22 & 23 & 38.33 \\
\hline 4. & 18 & 00 & 13 & 13 & 21.66 \\
\hline & Total & 25 & 35 & 60 & 100.0 \\
\hline
\end{tabular}

Source

Field Survey 
Table No. 1 shows that 01.67 per cent of the respondents are 15 year of age, 38.33 per cent of the respondents are 16 year of age, 38.33per cent are 17 year of age and 21.66 per cent are of 18 years old.

The table suggests that majority of the respondents are either 16 year or 17 year of age.

Table No.2

Native Place of the Respondents

\begin{tabular}{|c|c|c|c|c|c|}
\hline $\begin{array}{c}\text { SI.N } \\
\text { o }\end{array}$ & Native Place & P.U.C I & P.U.C II & $\begin{array}{c}\text { No. of } \\
\text { Respondents }\end{array}$ & Percent \\
\hline 1. & Rural & $\mathbf{1 0}$ & $\mathbf{0 9}$ & $\mathbf{1 9}$ & 31.66 \\
\hline 2. & Urban & 15 & $\mathbf{2 6}$ & $\mathbf{4 1}$ & $\mathbf{6 8 . 3 3}$ \\
\hline & Total & 25 & 35 & 60 & 100.0 \\
\hline
\end{tabular}

Source: Field Survey

Table no. 2 gives information about the native place of the respondent. It shows that 31.66 per cent of the respondents are from rural background and remaining 68.33 per cent are from urban background.

It can be concluded that due to an easy access to education in urban areas majority of the respondent pursuing education are from urban area and those coming from rural area reveal the fact that as the college have sound transportation they find it convenient to pursue education.

Table No. 3

Educational background of Respondent's Father

\begin{tabular}{|c|l|c|c|c|c|}
\hline $\begin{array}{c}\text { Sl. } \\
\text { No }\end{array}$ & Educational qualification & P.U.C I & P.U.C II & $\begin{array}{c}\text { No. of } \\
\text { Respondents }\end{array}$ & Percent \\
\hline 1. & Illiterate & 01 & 01 & 2 & $\mathbf{0 3 . 3 3}$ \\
\hline 2. & Primary & $\mathbf{0 8}$ & $\mathbf{0 8}$ & $\mathbf{0 6}$ & $\mathbf{2 6 . 6 6}$ \\
\hline 3. & Secondary & $\mathbf{0 8}$ & $\mathbf{1 4}$ & $\mathbf{2 2}$ & $\mathbf{3 6 . 6 6}$ \\
\hline 4. & Pre-University & $\mathbf{0 5}$ & $\mathbf{0 8}$ & $\mathbf{1 3}$ & $\mathbf{2 1 . 6 6}$ \\
\hline 5. & Graduate & $\mathbf{0 2}$ & $\mathbf{0 2}$ & $\mathbf{0 4}$ & $\mathbf{0 6 . 6 6}$ \\
\hline 6. & Post - Graduate & $\mathbf{0 1}$ & $\mathbf{0 1}$ & $\mathbf{0 2}$ & $\mathbf{0 3 . 3 3}$ \\
\hline 7. & Any other & $\mathbf{0 0}$ & $\mathbf{0 1}$ & $\mathbf{0 1}$ & $\mathbf{0 1 . 6 6}$ \\
\hline & Total & $\mathbf{2 5}$ & $\mathbf{3 5}$ & $\mathbf{6 0}$ & $\mathbf{1 0 0 . 0}$ \\
\hline
\end{tabular}

Source : $\quad$ Field Survey.

Note : $\quad$ Any other includes I.T.I.

Sound educational background is very much responsible for attaining higher education. Table No.3 gives the educational background of the respondent's father. The study shows that 03.33 per cent of the respondent fathers are illiterate, 26.66 per cent father had primary education, 36.66 per cent have education up to Secondary level, 21.66 per cent have completed Pre-university, 06.66 are Graduates, 03.33 per cent are Postgraduates and 01.66 falls under any other category.

The conclusion can be drawn with the help of the table that majority of respondents' father have education either upto primary or secondary level, thus it cannot be denied that they have awareness regarding education which further encouraged the respondents to pursue education.

Table No.4

Educational background of Respondent's Mother

\begin{tabular}{|c|l|c|c|c|c|}
\hline $\begin{array}{c}\text { Sl. } \\
\text { No }\end{array}$ & $\begin{array}{l}\text { Educational } \\
\text { qualification }\end{array}$ & P.U.C I & P.U.C II & $\begin{array}{c}\text { No. of } \\
\text { Respondents }\end{array}$ & Percent \\
\hline 1. & Illiterate & $\mathbf{0 3}$ & $\mathbf{0 3}$ & $\mathbf{0 6}$ & $\mathbf{1 0 . 0 0}$ \\
\hline 2. & Primary & $\mathbf{0 8}$ & $\mathbf{1 1}$ & $\mathbf{1 9}$ & $\mathbf{3 1 . 6 6}$ \\
\hline 3. & Secondary & $\mathbf{1 1}$ & $\mathbf{1 9}$ & $\mathbf{3 0}$ & $\mathbf{5 0 . 0 0}$ \\
\hline 4. & Pre-University & $\mathbf{0 1}$ & $\mathbf{0 2}$ & $\mathbf{0 3}$ & $\mathbf{0 5 . 0 0}$ \\
\hline 5. & Graduate & $\mathbf{0 2}$ & $\mathbf{0 0}$ & $\mathbf{0 2}$ & $\mathbf{0 3 . 3 3}$ \\
\hline 6. & Post - Graduate & $\mathbf{0 0}$ & $\mathbf{0 0}$ & $\mathbf{0 0}$ & $\mathbf{0 0 . 0 0}$ \\
\hline 7. & Any other & $\mathbf{0 0}$ & $\mathbf{0 0}$ & $\mathbf{0 0}$ & $\mathbf{0 0 . 0 0}$ \\
\hline & Total & $\mathbf{2 5}$ & $\mathbf{3 5}$ & $\mathbf{6 0}$ & $\mathbf{1 0 0 . 0}$ \\
\hline
\end{tabular}

Source: Field Survey. 
Table No.4 depicts the educational attainment of respondent's mother, it is revealed that 10.00 per cent of the respondent's mothers are illiterate, 31.66 per cent have attained Primary education, 50.00 per cent had Secondary education, 05.00 per cent have education up to Pre-university and 03.33 per cent are graduates. Thus we can conclude that majority of the respondent's mother had education only up to Secondary level and there is very less representation in Pre-University, Graduate and post-graduate level.

Table No.5

Occupational background of Respondents Father/Guardian

\begin{tabular}{|c|l|c|c|c|c|}
\hline $\begin{array}{c}\text { Sl. } \\
\text { No }\end{array}$ & Occupation & P.U.C I & P.U.C II & $\begin{array}{c}\text { No. of } \\
\text { Respondents }\end{array}$ & Percent \\
\hline 1. & Teacher & $\mathbf{0 0}$ & $\mathbf{0 3}$ & $\mathbf{0 3}$ & $\mathbf{0 5 . 0 0}$ \\
\hline 2. & Lecturer/Professor & $\mathbf{0 0}$ & $\mathbf{0 0}$ & $\mathbf{0 0}$ & $\mathbf{0 0 . 0 0}$ \\
\hline 3. & Lawyer & $\mathbf{0 0}$ & $\mathbf{0 0}$ & $\mathbf{0 0}$ & $\mathbf{0 0 . 0 0}$ \\
\hline 4. & Administrator & $\mathbf{0 0}$ & $\mathbf{0 0}$ & $\mathbf{0 0}$ & $\mathbf{0 0 . 0 0}$ \\
\hline 5. & Business & $\mathbf{1 6}$ & $\mathbf{2 0}$ & $\mathbf{3 6}$ & $\mathbf{6 0 . 0 0}$ \\
\hline 6. & Agriculture & $\mathbf{0 4}$ & $\mathbf{0 2}$ & $\mathbf{0 6}$ & $\mathbf{1 0 . 0 0}$ \\
\hline 7. & Religious Priest & $\mathbf{0 0}$ & $\mathbf{0 1}$ & $\mathbf{0 1}$ & $\mathbf{0 1 . 6 6}$ \\
\hline 8. & Private Service & $\mathbf{0 5}$ & $\mathbf{0 9}$ & $\mathbf{1 4}$ & $\mathbf{2 3 . 3 3}$ \\
\hline & Total & $\mathbf{2 5}$ & 35 & $\mathbf{6 0}$ & $\mathbf{1 0 0 . 0}$ \\
\hline
\end{tabular}

Source: Field Survey.

The occupational background of respondents father is depicted with the help of Table No. 5, the table shows that 05.00 per cent of the respondents father/guardian are Teacher, 60.00 per cent are in business, 10.00 per cent are performing agricultural activities, 01.66 are religious priest and 23.33 are engaged in private service.

The conclusion can be drawn that majority of the respondents Father/guardian are in Business sector.

Table No.6

Occupational background of the Respondents Mother

\begin{tabular}{|c|l|c|c|c|c|}
\hline SI.No & \multicolumn{1}{|c|}{ Occupation } & P.U.C I & P.U.C II & $\begin{array}{c}\text { No. of } \\
\text { Respondents }\end{array}$ & Percent \\
\hline 1. & Teacher & $\mathbf{0 1}$ & $\mathbf{0 1}$ & $\mathbf{0 2}$ & $\mathbf{0 3 . 3 3}$ \\
\hline 2. & Lecturer/Professor & $\mathbf{0 0}$ & $\mathbf{0 0}$ & $\mathbf{0 0}$ & $\mathbf{0 0 . 0 0}$ \\
\hline 3. & Lawyer & $\mathbf{0 0}$ & $\mathbf{0 0}$ & $\mathbf{0 0}$ & $\mathbf{0 0 . 0 0}$ \\
\hline 4. & Administrator & $\mathbf{0 0}$ & $\mathbf{0 0}$ & $\mathbf{0 0}$ & $\mathbf{0 0 . 0 0}$ \\
\hline 5. & Business & $\mathbf{0 0}$ & $\mathbf{0 4}$ & $\mathbf{0 4}$ & $\mathbf{0 6 . 6 6}$ \\
\hline 6. & Agriculture & $\mathbf{0 1}$ & $\mathbf{0 0}$ & $\mathbf{0 1}$ & $\mathbf{0 1 . 6 6}$ \\
\hline 7. & Religious Priest & $\mathbf{0 0}$ & $\mathbf{0 0}$ & $\mathbf{0 0}$ & $\mathbf{0 0 . 0 0}$ \\
\hline 8. & Housewife & $\mathbf{2 3}$ & $\mathbf{3 0}$ & $\mathbf{5 3}$ & $\mathbf{8 8 . 3 3}$ \\
\hline & Total & $\mathbf{2 5}$ & $\mathbf{3 5}$ & $\mathbf{6 0}$ & $\mathbf{1 0 0 . 0}$ \\
\hline
\end{tabular}

Source: Field Survey.

The occupational background of respondents' father is depicted using the Table No.6, the table shows that 03.33 per cent of the respondent mothers are Teacher, 06.66per cent are in business, 01.66 per cent are performing agricultural activities and 88.33 are Housewife.

Majority of the respondents' mother are housewife this is due to lack of higher education and lack of support for social mobility towards Muslim Women.

Table No.7

Ownership of Land by Respondents Family

\begin{tabular}{|c|l|c|c|c|c|}
\hline $\begin{array}{c}\text { Sl. } \\
\text { No }\end{array}$ & $\begin{array}{l}\text { Ownership of } \\
\text { Land }\end{array}$ & P.U.C I & P.U.C II & No. Respondents & Percent \\
\hline 1. & Yes & 10 & 17 & 27 & 45.00 \\
\hline 2. & No & 15 & 18 & 33 & 55.00 \\
\hline & Total & 25 & 35 & 60 & 100.0 \\
\hline
\end{tabular}

Source : $\quad$ Field Survey. 
Table No. 7 exhibits Ownership of land by the respondent's family which shows the economic background of the respondents. The table displays that 45.00 per cent of the respondent's families have land and 55.00 per cent do not have land.

The conclusion can be drawn on the basis of the table that majority of the respondent do not have ownership of land this may be due to poverty as most of them are from either middle class background or low income group.

Table No. 8

Nature of Land $\mathbf{N}=\mathbf{2 7}$

\begin{tabular}{|c|l|c|c|c|}
\hline Sl.No & Nature of Land & P.U.C I & P.U.C II & Percent \\
\hline 1. & Dry Land & 08 & 15 & 85.18 \\
\hline 2. & Irrigated Land & 06 & 06 & 44.44 \\
\hline
\end{tabular}

Source: Field Survey.

Table No. 8 depicts that out of total 27 respondents 85.18 per cent of the respondents have Dry Land and 44.44 have Irrigated Land. On the basis of earlier table it can be deduced, as most of the respondents are from urban background and the representation of the respondents having dry land is more as compared to irrigated land.

Table No.9

Nature of the Family

\begin{tabular}{|c|l|c|c|c|c|}
\hline $\begin{array}{c}\text { SI. } \\
\text { No }\end{array}$ & Nature & P.U.C I & P.U.C II & $\begin{array}{c}\text { No. of } \\
\text { Respondents }\end{array}$ & Percent \\
\hline 1. & Joint Family & 00 & 07 & 07 & 11.66 \\
\hline 2. & Nuclear Family & 25 & 28 & 53 & $\mathbf{8 8 . 3 3}$ \\
\hline & Total & 25 & 35 & $\mathbf{6 0}$ & 100.0 \\
\hline
\end{tabular}

Source: Field Survey.

The nature of family of the respondents is revealed in the Table No. 9, the table shows that 11.66 per cent of the respondents live in Joint Family and remaining 88.33 per cent are living in Nuclear family.

Thus we can conclude that as most of the respondents are from urban background thus the percent of respondents living in nuclear family is more as compared to Joint family.

Table No.10

Monthly Income of the Respondents' Father/Guardian.

\begin{tabular}{|c|l|c|c|c|c|}
\hline $\begin{array}{c}\text { Sl.N } \\
\text { o }\end{array}$ & Income ( In Rupees) & P.U.C I & P.U.C II & $\begin{array}{c}\text { No. of } \\
\text { Respondents }\end{array}$ & Percent \\
\hline 1. & Less than 5,000 & 06 & 09 & 15 & 25.00 \\
\hline 2. & $\mathbf{5 , 0 0 1 - 1 0 , 0 0 0}$ & $\mathbf{1 0}$ & $\mathbf{0 8}$ & $\mathbf{1 8}$ & $\mathbf{3 0 . 0 0}$ \\
\hline 3. & $\mathbf{1 0 , 0 0 1 - 1 5 , 0 0 0}$ & $\mathbf{0 1}$ & $\mathbf{0 8}$ & $\mathbf{0 9}$ & $\mathbf{1 5 . 0 0}$ \\
\hline 4. & $\mathbf{1 5 , 0 0 1 - 2 0 , 0 0 0}$ & $\mathbf{0 4}$ & $\mathbf{0 6}$ & $\mathbf{1 0}$ & $\mathbf{1 6 . 6 6}$ \\
\hline $\mathbf{5 .}$ & $\mathbf{2 0 , 0 0 1 - 2 5 0 0 0}$ & $\mathbf{0 1}$ & $\mathbf{0 3}$ & $\mathbf{0 4}$ & $\mathbf{0 6 . 6 6}$ \\
\hline $\mathbf{6 .}$ & Above 25,000 & $\mathbf{0 3}$ & $\mathbf{0 1}$ & $\mathbf{0 4}$ & $\mathbf{0 6 . 6 6}$ \\
\hline & Total & $\mathbf{2 5}$ & $\mathbf{3 5}$ & $\mathbf{6 0}$ & $\mathbf{1 0 0 . 0}$ \\
\hline
\end{tabular}

Source: Field Survey.

The economic background of the respondents is shown using the Table No.10. The table suggests that 25.00 per cent of the respondents father/guardian have the monthly income of less than Rs. 5,000, 30.00 per cent have income of Rs.5, 001-10,000, 15.00 per cent have the income of Rs.10, 001-15,000, 16.66 per cent have the income of Rs. 15,001-20,000, 06.66 per cent have the monthly income of Rs. 20,001-25000 and 06.66 per cent of the respondents father/guardian have the income of above Rs.25, 000.

Thus it is exhibited from the given table that most of the respondents belong to lower middle class group. 
Table No.11

Percentage scored by the respondents in the last examination

\begin{tabular}{|c|l|c|c|c|c|}
\hline $\begin{array}{c}\text { SI. } \\
\text { No }\end{array}$ & Percentage & P.U.C I & P.U.C II & $\begin{array}{c}\text { No. of } \\
\text { Respondents }\end{array}$ & Percent \\
\hline 1. & $\mathbf{3 5 - 5 0}$ & $\mathbf{0 2}$ & 13 & 15 & 25.00 \\
\hline 2. & $\mathbf{5 1 - 6 0}$ & 10 & 12 & 22 & 36.66 \\
\hline 3. & $\mathbf{6 1 - 7 5}$ & $\mathbf{1 0}$ & $\mathbf{0 7}$ & $\mathbf{1 7}$ & $\mathbf{2 8 . 3 3}$ \\
\hline 4. & $\mathbf{7 6 - 8 5}$ & $\mathbf{0 3}$ & $\mathbf{0 3}$ & $\mathbf{0 6}$ & $\mathbf{1 0 . 0 0}$ \\
\hline 5. & Above 85 & $\mathbf{0 0}$ & $\mathbf{0 0}$ & $\mathbf{0 0}$ & $\mathbf{0 0 . 0 0}$ \\
\hline & Total & $\mathbf{2 5}$ & $\mathbf{3 5}$ & $\mathbf{6 0}$ & $\mathbf{1 0 0 . 0}$ \\
\hline
\end{tabular}

Source: Field Survey.

Table No.11 discloses the percentage-wise classification of marks of the respondents, it shows that 25.00 per cent of the respondents have scored 35-50 per cent, 36.66 per cent have $51-60$ per cent, 28.33 per cent have $61-75$ per cent, and remaining 10.00 per cent of them have $76-85$ per cent.

The information reveals that nearly most of the respondents are either in the group of 51-60 or 61-75 percentages. It can be said that majority of the respondent have average performance in their studies.

Table No.12

Medium of Instruction in Teaching $\mathbf{N}=60$

\begin{tabular}{|c|l|c|c|c|c|}
\hline $\begin{array}{c}\text { Sl. } \\
\text { No }\end{array}$ & Medium & P.U.C I & P.U.C II & $\begin{array}{c}\text { No. of } \\
\text { Respondents }\end{array}$ & Percent \\
\hline 1. & English & 25 & 35 & $\mathbf{6 0}$ & $\mathbf{1 0 0}$ \\
\hline 2. & Urdu & $\mathbf{2 5}$ & $\mathbf{3 5}$ & $\mathbf{6 0}$ & $\mathbf{1 0 0}$ \\
\hline 3. & Kannada & $\mathbf{0 0}$ & $\mathbf{0 0}$ & $\mathbf{0 0}$ & $\mathbf{0 0 . 0}$ \\
\hline
\end{tabular}

Source : $\quad$ Field Survey.

The medium of instruction of the respondents is shown in the Table No.12, it shows that medium of instruction in Al-Ameen college is English as well as Urdu language.

On the basis of the table and field survey it is realized that the medium of instruction in Al-Ameen College is English and on the other hand as majority of the students have pursued their schooling from Urdu Medium schools and belong to Muslim community the medium of Instruction is also in Urdu for the convenience and understanding of the students

Table No.13

Medium of Instruction in Examination

\begin{tabular}{|c|l|c|c|c|c|}
\hline $\begin{array}{c}\text { Sl. } \\
\text { No }\end{array}$ & Medium & P.U.C I & P.U.C II & $\begin{array}{c}\text { No. of } \\
\text { Respondents }\end{array}$ & Percent \\
\hline 1. & English & $\mathbf{2 5}$ & $\mathbf{3 5}$ & $\mathbf{6 0}$ & $\mathbf{1 0 0}$ \\
\hline 2. & Urdu & $\mathbf{0 0}$ & $\mathbf{0 0}$ & $\mathbf{0 0}$ & $\mathbf{0 0}$ \\
\hline 3. & Kannada & $\mathbf{0 0}$ & $\mathbf{0 0}$ & $\mathbf{0 0}$ & $\mathbf{0 0}$ \\
\hline
\end{tabular}

Source

Field Survey

The medium of instruction of the respondents is shown in the Table No.13, it shows that 100 per cent of the respondents have English medium. It can be understood with the help of the table that majority of the respondents have English medium as their medium of Instruction in the Examination.

As average numbers of students are from Urdu medium schools they lack proficiency in Kannada language and there is no other alternate for them rather than to take English medium. 
Table No.14

Languages known by the Respondents

\begin{tabular}{|c|l|c|c|c|c|}
\hline $\begin{array}{c}\text { Sl. } \\
\text { No }\end{array}$ & Languages Known & P.U.C I & P.U.C II & $\begin{array}{c}\text { No. of } \\
\text { Respondents }\end{array}$ & Percent \\
\hline 1. & Urdu & 00 & 00 & 00 & 00.00 \\
\hline 2. & Urdu, English & 15 & 12 & 27 & 45.00 \\
\hline 3. & $\begin{array}{l}\text { Urdu, English \& } \\
\text { Hindi }\end{array}$ & 05 & 08 & 13 & 21.66 \\
\hline 4 & $\begin{array}{l}\text { Urdu, English \& } \\
\text { Kannada }\end{array}$ & 04 & 15 & 19 & 31.66 \\
\hline 5 & $\begin{array}{l}\text { Urdu, English, Kannada, Hindi \& } \\
\text { Arabic }\end{array}$ & 01 & 00 & 01 & 01.66 \\
\hline 6 & $\begin{array}{l}\text { Urdu, English, Kannada, Hindi, } \\
\text { Arabic \& Marathi }\end{array}$ & 00 & 00 & 00 & 00.00 \\
\hline
\end{tabular}

Source : $\quad$ Field Survey.

The languages known by the respondent to read as well as to write is depicted in the Table No.14. It suggests that 45 per cent of the respondents know Urdu \& English, 21.66 per cent know Urdu, English \& Hindi, 31.66 per cent knows Urdu, English and Kannada and the remaining 01.66 per cent of them know Urdu, English, Kannada, Hindi and Arabic. Kannada.

The majority of the respondents fall either in the category of Urdu and English or Urdu, English and

Table No.15

Opinion about English Language

\begin{tabular}{|c|l|c|c|c|c|}
\hline $\begin{array}{c}\text { SI. } \\
\text { No }\end{array}$ & Opinion & P.U.C I & P.U.C II & $\begin{array}{c}\text { No. of } \\
\text { Respondents }\end{array}$ & Percent \\
\hline 1. & Very Difficult & 00 & 00 & 00 & 00.00 \\
\hline 2. & Difficult & 05 & 15 & 20 & 33.33 \\
\hline 3. & Easy & $\mathbf{2 0}$ & $\mathbf{1 9}$ & 39 & $\mathbf{6 5 . 0 0}$ \\
\hline 4. & Very Easy & $\mathbf{0 0}$ & $\mathbf{0 1}$ & $\mathbf{0 1}$ & $\mathbf{0 1 . 6 6}$ \\
\hline & Total & $\mathbf{2 5}$ & $\mathbf{3 5}$ & $\mathbf{6 0}$ & $\mathbf{1 0 0 . 0}$ \\
\hline
\end{tabular}

Source : $\quad$ Field Survey.

The respondents have different opinion about English language and this is reveled in the table No.15, It shows that, 33.33 per cent felt that English is a difficult language, 65.00 per cent opine it as easy and only 01.66 per cent say that it is very easy.

Here the conclusion can be drawn that majority of the respondent feel that English language is easy for them.

Table No.16

Participation in Sports \& Cultural Activities

\begin{tabular}{|c|l|c|c|c|c|}
\hline $\begin{array}{c}\text { Sl. } \\
\text { No }\end{array}$ & $\begin{array}{l}\text { Participation } \\
\text { in Activities }\end{array}$ & P.U.C I & P.U.C II & $\begin{array}{c}\text { No. of } \\
\text { Respondents }\end{array}$ & Percent \\
\hline 1. & Yes & 23 & 28 & 51 & $\mathbf{8 5 . 0 0}$ \\
\hline 2. & No & 02 & 07 & 09 & 15.00 \\
\hline & Total & 25 & 35 & 60 & 100.0 \\
\hline
\end{tabular}

Source : $\quad$ Field Survey.

The participation in sports and cultural activities by the respondent is shown with the help of the Table No.16. It informs that 85.00 per cent of them participate in sports and cultural activities and the remaining 15.00 per cent do not participate in sports and cultural activities.

It can be understood with the given table that majority i.e., 85 of the girl students pursuing education participate in sports and cultural activities. 
Table No. 17

Type of sport in which the respondents participate

\begin{tabular}{|c|l|c|c|c|c|}
\hline $\begin{array}{c}\text { Sl. } \\
\text { No }\end{array}$ & Type of sport & P.U.C I & P.U.C II & $\begin{array}{c}\text { No. of } \\
\text { Respondents }\end{array}$ & Percent \\
\hline 1. & Indoor sport & 15 & 19 & 34 & 66.66 \\
\hline 2. & Outdoor Sport & 22 & 19 & 41 & 80.39 \\
\hline
\end{tabular}

Source : $\quad$ Field Survey.

Table No. 17 informs about participation of respondents in sports activities, here the sports activities are classified into indoor and outdoor games. It shows that 66.66 percent of the total respondent participates in Indoor games and 80.39 percent participate in Outdoor sport.

Table No. 18

Activities in which the respondents Participate $\mathbf{N}=\mathbf{5 1}$

\begin{tabular}{|c|l|c|c|c|c|}
\hline $\begin{array}{c}\text { Sl. } \\
\text { No }\end{array}$ & Activities & P.U.C I & P.U.C II & $\begin{array}{c}\text { No. of } \\
\text { Respondents }\end{array}$ & Percent \\
\hline 1. & Singing & $\mathbf{1 1}$ & $\mathbf{1 6}$ & $\mathbf{2 7}$ & $\mathbf{5 2 . 9 4}$ \\
\hline 2. & Elocution & $\mathbf{0 8}$ & $\mathbf{0 5}$ & $\mathbf{1 3}$ & $\mathbf{2 5 . 4 9}$ \\
\hline 3. & Debate & $\mathbf{0 1}$ & $\mathbf{0 0}$ & $\mathbf{0 1}$ & $\mathbf{0 1 . 9 6}$ \\
\hline 4. & Extempore & $\mathbf{0 1}$ & $\mathbf{0 2}$ & $\mathbf{0 3}$ & $\mathbf{0 5 . 8 8}$ \\
\hline 5. & Quiz & $\mathbf{0 7}$ & $\mathbf{0 7}$ & $\mathbf{1 4}$ & $\mathbf{2 7 . 4 5}$ \\
\hline 6. & Essay Writing & $\mathbf{1 2}$ & $\mathbf{0 9}$ & $\mathbf{2 1}$ & $\mathbf{4 1 . 1 7}$ \\
\hline 7. & Any Other & $\mathbf{0 7}$ & $\mathbf{1 0}$ & $\mathbf{1 7}$ & $\mathbf{3 3 . 3 3}$ \\
\hline
\end{tabular}

Source : $\quad$ Field Survey.

Note : $\quad$ Any other Includes Drama, Mehandi, Dancing \& Mono Acting.

It is revealed from the above table that 52.94 percent are interested in participating in singing, 25.49 percent in elocution, 01.96 percent in debate, 5.88 percent in extempore, 27.45 in quiz, 41.17 percent and 33.33 percent likes to participate other cultural activities like drama, mehandi, dancing and mono acting.

Thus we can say that majority of the respondents are interested in participating in singing and the number of participants in essay writing is more as compared to other activities.

Table No.19

Encouragement and support to pursue Education

$\mathbf{N}=60$

\begin{tabular}{|c|l|c|c|c|c|}
\hline $\begin{array}{c}\text { SI. } \\
\text { No }\end{array}$ & $\begin{array}{l}\text { Support to pursue college } \\
\text { education }\end{array}$ & P.U.C I & P.U.C II & $\begin{array}{c}\text { No. of } \\
\text { Respondent }\end{array}$ & Percent \\
\hline 1. & Father & 07 & 08 & 15 & 25.00 \\
\hline 2. & Mother & 05 & 03 & 08 & 13.33 \\
\hline 3. & Both Father \&Mother & 13 & 24 & 37 & $\mathbf{6 1 . 6 6}$ \\
\hline 4. & Brother/s & 07 & 09 & 16 & 26.66 \\
\hline 5. & Sister/s & 08 & 18 & 26 & 43.33 \\
\hline 6. & Relatives & 09 & 14 & 23 & 38.33 \\
\hline 7. & Friend/s & 04 & 09 & 13 & 21.66 \\
\hline 8. & Teacher/s & 16 & 24 & 40 & 66.66 \\
\hline
\end{tabular}

Source : $\quad$ Field Survey.

Encouragement and support is very much essential in education of the girl student. Table No. 19 exhibits the encouragement and support to pursue higher education, it reveals that 25 per cent of the respondents received encouragement from their Father, 13.33 per cent from Mother, 61.66 percent of the respondents received encouragement from both Father and Mother, 26.66 per cent from Brother, 43.33 per cent from Sister, and 38.33 per cent from Relatives, 21.66 from Friends and 66.66 from Teachers.

It reveals that majority of the respondents received encouragement and support from their Parents and Teachers which proves the fact that "teacher is the second parent". 
Table No.20

Reason for not pursuing Technical Education

\begin{tabular}{|c|l|c|c|c|c|}
\hline $\begin{array}{c}\text { SI. } \\
\text { No }\end{array}$ & Reasons & P.U.C I & P.U.C II & $\begin{array}{c}\text { No. of } \\
\text { Respondents }\end{array}$ & Percent \\
\hline 1. & Poverty & 05 & 07 & 12 & 20.00 \\
\hline 2. & Less marks in S.S.L.C. & 00 & 04 & 04 & 06.66 \\
\hline 3. & Lack of English knowledge & 00 & 02 & 02 & 03.33 \\
\hline 4. & Lack of proper guidance & $\mathbf{0 3}$ & $\mathbf{0 4}$ & $\mathbf{0 7}$ & $\mathbf{1 1 . 6 6}$ \\
\hline 5. & Not applicable & 17 & $\mathbf{1 8}$ & $\mathbf{3 5}$ & $\mathbf{5 8 . 3 3}$ \\
\hline & Total & $\mathbf{2 5}$ & $\mathbf{3 5}$ & $\mathbf{6 0}$ & $\mathbf{1 0 0 . 0}$ \\
\hline
\end{tabular}

\section{Source : $\quad$ Field Survey}

As most of the respondents are pursuing non-technical education Table No.20 shows the reason for not pursuing the technical education, it shows 20.00 per cent of them are not pursuing technical education as they suffer from poverty, 06.66 per cent due to less marks in S.S.L.C. examination, 03.33 per cent due to lack of English knowledge and 11.66 per cent lack of proper guidance and the remaining 58.33per cent comes under not applicable because they are highly interested to pursue education in Arts discipline.

The average number of the respondents did not pursue technical education because they have willingly joined arts stream.

Table No.21

Reason for getting College education

\begin{tabular}{|c|l|c|c|c|c|}
\hline $\begin{array}{c}\text { Sl. } \\
\text { No. }\end{array}$ & Reasons & P.U.C I & P.U.C II & $\begin{array}{c}\text { No. of } \\
\text { Respondents }\end{array}$ & Percent \\
\hline 1. & Importance of Education & 18 & 25 & 43 & 71.66 \\
\hline 2. & Govt. Scholarship & 02 & 01 & 03 & $\mathbf{0 5 . 0 0}$ \\
\hline 3. & Economic Prosperity & 04 & 04 & 08 & 13.33 \\
\hline 4. & Any other & 01 & 05 & 06 & 10.00 \\
\hline & Total & 25 & 35 & $\mathbf{6 0}$ & 100.0 \\
\hline
\end{tabular}

Source : $\quad$ Field Survey.

Note : $\quad$ Any other includes for spending spare time

One or other reasons influence education among of the girls; this is displayed with the help of Table No. 21. It reveals that 71.66 per cent of the respondents are pursuing education as they feel education is very important, 05.00 percent of them have enrolled as they depend on government scholarship facility, 13.33 per cent are pursuing education as they aspire to attain economic prosperity through education and 10.00 percent do not have any aim they just want to spend their spare time.

The conclusion can be drawn on the basis of the above table that majority of the respondents have importance of education this very much shows that the muslim girls are not only pursuing education but they also have importance of education for their overall development and prosperity.

Table No.22

Aim of the Respondent

\begin{tabular}{|c|l|c|c|c|c|}
\hline $\begin{array}{c}\text { Sl. } \\
\text { No }\end{array}$ & Aims & P.U.C I & P.U.C II & $\begin{array}{c}\text { No. of } \\
\text { Respondents }\end{array}$ & Percentage \\
\hline 1. & Teaching & 22 & 21 & 43 & 71.66 \\
\hline 2. & Business & 01 & 05 & 06 & 10.00 \\
\hline 3. & Advocate & 00 & 03 & 03 & 05.00 \\
\hline 4. & Politician & 00 & 00 & 00 & 00.00 \\
\hline 5. & Social Worker & 00 & 01 & 01 & 01.66 \\
\hline 6. & Any Other & 02 & 04 & 06 & 10.00 \\
\hline 7. & No response & 00 & 01 & 01 & 01.66 \\
\hline & Total & 25 & 35 & 00 & 100.0 \\
\hline
\end{tabular}

Source : $\quad$ Field Survey.

Note : : Any other refers to job in any government department.

The respondents have specific aim in their future course of life and the Table No.22 shows that 71.66 per cent of them aim to have Teaching as their profession, 10 percent are interested in business, 05 percent aspire to become an Advocate, 01.66 per cent wants to do social work, 10 percent falls in any other category i.e., they wish to serve in any government department and remaining 01.66 do not have any idea of future prospect. 
Thus we can conclude that majority of the respondent aims to acquire Teaching as their career and there is none who is interested to join politics this may be due to increase in criminalisation of politics and low political values.

Table No.23

Newspaper Reading habit of the Respondents

\begin{tabular}{|c|l|c|c|c|c|}
\hline $\begin{array}{c}\text { Sl. } \\
\text { No }\end{array}$ & Opinions & P.U.C I & P.U.C II & $\begin{array}{c}\text { No. of } \\
\text { Respondents }\end{array}$ & Percent \\
\hline 1. & Yes & 22 & 32 & 54 & 90.00 \\
\hline 2. & No & 03 & 03 & 06 & 10.00 \\
\hline & Total & 25 & 35 & 60 & 100 \\
\hline
\end{tabular}

Source : $\quad$ Field Survey.

Table No. 23 reveals that 90 percent of the respondents read newspaper while 10 percent of the respondents do not read newspaper.

On the basis of the above table it can be realised that majority of the respondents read newspaper as the newspaper keeps them up to date regarding the present scenario and reading of newspaper during the prayer is an obligation in Al-Ameen College.

Table No.24

Whether College education helps in removing social inequality

\begin{tabular}{|c|l|c|c|c|c|}
\hline $\begin{array}{c}\text { Sl. } \\
\text { No }\end{array}$ & Opinions & P.U.C I & P.U.C II & $\begin{array}{c}\text { No. of } \\
\text { Respondents }\end{array}$ & Percent \\
\hline 1. & Yes & 23 & 30 & 53 & 88.33 \\
\hline 2. & No & 02 & 05 & 07 & 11.66 \\
\hline & Total & 25 & 35 & 60 & 100 \\
\hline
\end{tabular}

Source : $\quad$ Field Survey.

The opinions of the respondent regarding, whether education helps in removing social inequality is explained using the Table No.24, it reveals that 88.33 per cent of the respondents say that education helps in removing social inequality and only 11.66 per cent opines that education doesn't remove social inequality. Those who do not support education helps in removing social inequality express that most of the social inequality is enforced by the educated class.

On the basis of the above table we can conclude that majority of the respondent supports that education helps in removing social inequality.

Table No. 25

Type of Education Required for the Girl Student

\begin{tabular}{|c|l|c|c|c|c|}
\hline $\begin{array}{c}\text { Sl. } \\
\text { No. }\end{array}$ & Education required & P.U.C I & P.U.C II & $\begin{array}{c}\text { No. of } \\
\text { Respondents }\end{array}$ & Percent \\
\hline 1. & Technical & $\mathbf{0 0}$ & $\mathbf{0 6}$ & $\mathbf{0 6}$ & $\mathbf{1 0 . 0 0}$ \\
\hline 2. & Self Employment & $\mathbf{0 0}$ & $\mathbf{0 2}$ & $\mathbf{0 2}$ & $\mathbf{0 3 . 3 3}$ \\
\hline 3. & Higher Education & $\mathbf{2 4}$ & $\mathbf{2 7}$ & $\mathbf{5 1}$ & $\mathbf{8 5 . 0 0}$ \\
\hline 4. & Religious Education & $\mathbf{0 1}$ & $\mathbf{0 0}$ & $\mathbf{0 1}$ & $\mathbf{0 1 . 6 6}$ \\
\hline & Total & $\mathbf{2 5}$ & $\mathbf{3 5}$ & $\mathbf{6 0}$ & $\mathbf{1 0 0 . 0}$ \\
\hline
\end{tabular}

Source : $\quad$ Field Survey.

The suggestion of the respondents regarding the type of education required for the girl student is depicted in the Table No. 25, shows that 10.00 per cent of them suggest Technical education, 03.33 per cent self-employment, 85.00 per cent suggests higher education and remaining 01.66 percent suggest religious education.

The conclusion can be drawn that majority of them suggests there is an utmost necessity for girls to get higher education.

\section{Major Findings \& Conclusion:}

Some of the major findings of the present study entitled "Silhoutte of Muslim Minority Girls Pursuing College Education: A Case study of Al-Ameen College, Belgaum” are as follows:

- The respondents pursuing education in Al-Ameen Pre-University College have more representation of students coming from urban area as compared to rural area and as they are from urban area they belong to nuclear family. 
- Encouragement for getting education by the parents and teachers of the respondents is exhibited as most of the parents are literate they give importance to educate the girl child.

- As far as the occupational and economic background of the respondents is concerned majority of the respondents Father/guardian are involved in Business activities most of them not only lack ownership of land but they also fall in middle lower income group.

- Most of the respondent's mothers are housewife this shows lack of support for social mobility of women or as most of the mothers do not have higher education thus they lack better employment opportunities.

- The performance of respondents in their previous exam shows that most of them are average in their studies.

- The most notable fact which is revealed in the present study is that though the respondents are from Urdu medium background they find English as an easy language and their medium of writing examination is in English.

- The important contributory part of Al-Ameen Pre-University College is the medium of instruction as the medium of Instruction in Al-Ameen College is English but on the other hand as majority of the students have pursued their schooling from Urdu Medium schools and belong to Muslim community the medium of Instruction is also in Urdu for the convenience and understanding of the students.

- Majority of the respondents aspire to have teaching as their career and none of them is interested in joining politics this may be due to increase in criminalisation of politics and low political values.

- The respondents have the habit of reading of newspaper regularly as it is a routine to read the newspaper during the assembly at the time of prayer which keeps them up-to -date about major current issues.

- Average number of the respondents pursuing college education at Al-Ameen College, Belgaum opines that education helps in removing social inequality and they support higher education for the Muslim girls.

\section{References}

[1] Anita Nuna, 'Education of Muslim Girls: A Study of the Area Intensive Programme', Programme Coordinator, Department of Women's Studies, National Council of Educational Research and Training, Sri Aurobindo Marg, New Delhi, 2003

[2] B.C.Rai., 'HIory of Indian Education \& Problems', Prakashan Kendra, Lucknow, 2003.

[3] Bhatty, Zarina, (ed.), 'Status of Muslim Women and Social Change, Indian Women: From Purdah to Modernity', Vikas Publishing House, New Delhi, 1976.

[4] Chitra, M.N., 'Higher Education and Society in Mysore under British rule', Sociological Bulletin, $21(2), 1972$.

[5] Fegin, Joe R. 'Racial and Ethnic Relations', Prentice-Hall, New Jersey, 1984

[6] Hashia Haseena (ed.), 'Muslim Women in India since Independence (Feminine Perspectives)', Institute of Objective Studies, First Edition, 1998.

[7] Shah, S. Shamim, 'Educational Survey on Muslim Managed Schools and Colleges in India with Special Emphasis on Science Education', Hamdard Education Society Publication, 1982-83, New Delhi.

[8] Usha Nayar, 'An Analytical Study of Education of Muslim Women and Girls in India', New Delhi, October 1, 2007

[9] Z. A. Pathan, 'Muslim Elite: A Sociological Analysis', Serials Publications, New Delhi, 2006

[10] Zoya Hasan, \& Ritu Menon, 'Educating Muslim Girls: A Comparison of Five Cities', women unlimited, 2005 